
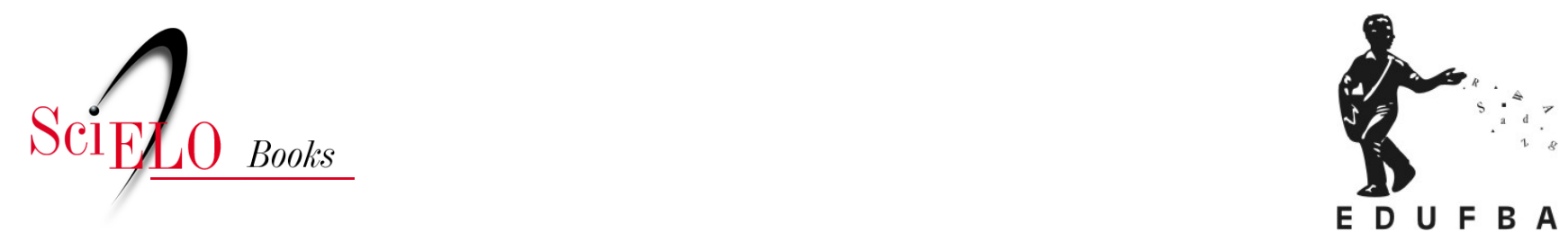

\title{
4. A poética do corpo no samba de roda das margens do Velho Chico
}

\author{
Nerivaldo Alves Araújo
}

\section{SciELO Books / SciELO Livros / SciELO Libros}

ARAÚJO, N.A. A poética do corpo no samba de roda das margens do Velho Chico. In: Poética oral do samba de roda das margens do Velho Chico [online]. Salvador: EDUFBA, 2016, pp. 103-123. ISBN: 978-85-232-2031-0. https://doi.org/10.7476/9788523220310.0005.

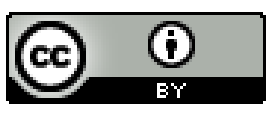

All the contents of this work, except where otherwise noted, is licensed under a Creative Commons Attribution 4.0 International license.

Todo o conteúdo deste trabalho, exceto quando houver ressalva, é publicado sob a licença Creative Commons Atribição 4.0. 



\section{A poética do corpo no samba de roda das margens do Velho Chico}

Nas rodas de samba do grupo "É na pisada ê", o corpo configura-se como um instrumento que, aliado às composições poéticas, produz toda uma linguagem performática, a qual se mantém viva na própria memória corporal do sambador, pois o corpo pode ser visto, também, como espaço de memória, o qual faz emergir as tradições de um povo.

Esses corpos que sambam, juntamente com a voz em cantos cadenciados e marcados pelas palmas e outros instrumentos sonoros, proporcionam uma manifestação teatral que percorre o tempo e a história do seu povo, verdadeiros atores. Mas atores diferentes, em diferentes lugares e épocas. Esses atores se servem de uma performance que cada vez se constrói de forma singular, pois cada roda de samba é única, formando assim um novo espaço simbólico composto de tradições reinventadas.

Como afirmam Hobsbawm e Ranger (2002), as tradições reinventadas podem ser consideradas como um conjunto de práticas de natureza ritual ou simbólica, que visam a inculcar certos valores e normas comportamentais através da repetição, implicando, automaticamente, uma continuidade em relação a um passado histórico apropriado. Hobsbawm e Ranger consideram ainda que a invenção das tradições seja "essencialmente um processo de formalização e ritualização, caracterizado por se referir ao passado, mesmo que apenas pela imposição da repetição”. (HOBSBAWM; RANGER, 2002, p. 12)

Trata-se, contudo, de uma repetição sistematizada, na qual alguns elementos como músicas, danças e gestos chegam a se repetir, mas, em outro momento, em outra circunstância, muitas vezes com objetivos diferenciados. Isso se configura porque, conforme Zumthor (2010), em toda performance há, como um fragmento "ficticionalmente" isolado do tempo real, um conjunto de valores próprios que, na maioria das vezes, mudam e se invertem em cada apresentação. 
Nesse sentido, entende-se que a performance se mantém vinculada a uma espécie de memória cultural. Através dessa memória cultural, o corpo passa a repetir, nas rodas de samba, a dança e os passos, não de maneira idêntica, mas trazendo as suas marcas, gingados, giros e pisadas. Isso permite considerar cada uma dessas rodas como uma apresentação única, um espetáculo inédito da cultura local.

Dentro de todo um universo performático, o corpo assume um lugar de destaque na poética oral ribeirinha. As cantigas do samba de roda se completam da performance corporal para retratar as identidades, manter vivas as tradições do povo das margens do Velho Chico. Esse corpo passa a se constituir, juntamente com as cantigas e suas letras, como um lugar de memória, de preservação das tradições, de avivamento de emoções. Através de seus movimentos, de suas danças, esse corpo passa então, a atuar como um ativador da memória, podendo ser tido como um espaço motivador de uma memória, que, muitas vezes, pelas circunstâncias, é esquecida.

A memória, conforme aponta Bergson (1999), não consiste, em absoluto, num retorno do presente ao passado, mas, sim, numa forma de progredir do passado ao presente. Esse passado configura-se como ponto de partida de um "estado virtual". Ainda para o referido autor, isso se dá através de uma série de planos de consciência diferentes, até o momento em que essa virtualidade dá lugar a um estado presente e atuante, num plano extremo de consciência em que se desenha o nosso corpo.

Sendo assim, no grupo de samba "É na pisada ê", o corpo registra, no presente, uma memória reescrita em gestos, giros e pisadas, cujas emoções são as gestoras desse translado do passado virtual ao presente atuante, pois o tempo é outro, a realidade é outra, e as intenções também podem não ser exatamente as mesmas.

A memória desenhada pelo corpo - que samba, requebra, gira e se realiza dentro de um cenário contextualizado - permite, através da repetição, a perpetuação das tradições, as quais jamais serão cópia exata do que se guarda na memória, mas um conjunto de lembranças que se reinventam e se reconstroem no presente, em meio a intenções e ideologias.

As sambadeiras e sambadores trazem, no corpo, a memória de um passado que, em suas performances, presentificam-no como parte de uma ancestralidade coletiva. A umbigada, por exemplo, é uma presentificação dessa memó- 
ria que permanece nas rodas de hoje, adequando-se à realidade, ao contexto, embora venha de uma tradição antiga, de povos ancestrais, nesse caso, de afrodescendentes.

Na cantiga em que se representa a dança da piranha, brinca-se com a imitação de uma piranha agitada e sua maneira voraz e eufórica de atacar a presa, de devorar o alimento. A brincadeira é, portanto, encerrada com a umbigada para convidar a outra sambadeira ao centro, como tradicionalmente era feito, desde o surgimento da dança na região. Adiante, segue, mais uma vez, a cantiga, a fim de se perceber a presença da umbigada como marca da memória corporal:

Dançou, dançou, piranha

Tornou dançar, piranha

Com a mão na cabeça, piranha

Com a mão na cintura, piranha

Dá um jeitinho no corpo, piranha

E uma umbigada na outra, piranha

Os próprios giros em torno do corpo, a "pisadinha” e a formação em rodas também são marcas de uma tradição do passado que se concretiza no samba de roda nos dias atuais. A própria composição literária é um espaço de memória que dá vazão às emoções, pois os temas, muitas vezes, retratam fatos do passado, lembranças que permanecem vivas em um presente festivo e alegre.

Todo o corpo, em sua mais singular expressão, carrega, em si, durante as apresentações das rodas de samba, a memória de ancestrais, servindo, nesses momentos, como um instrumento, por meio do qual, esboça-se o retrato das identidades de sua gente. As palmas, em ritmos sincopados, marcados, permanecem também na memória desse corpo. A própria voz e a sonoridade, ao entoar as cantigas, são aspectos que também ajudam a construir a poética do corpo no samba de roda. É o corpo, através da sua memória, que produz a voz, a melodia, a poesia e o seu modo de expressão.

Através dos seus movimentos nas danças, o corpo passa a ativar a memória do sambador, agindo como um motivador das lembranças que emergem dessas águas poéticas na região de Xique-Xique, fazendo que venham à baila outros passos, outras performances, outras representações da tradição. Essa memória representa a própria vida, pois, conforme Nora (1981), memória é vida carrega- 
da por grupos vivos, mantendo-se sempre em evolução, aberta à dialética da lembrança e do esquecimento, inconsciente de suas deformações, vulneráveis a usos e manipulações.

As marcas da ancestralidade permanecem no corpo através da sua memória. Logo, esse corpo, que samba nas margens do Velho Chico, permite reviver um passado, muitas vezes, marcado pela discriminação e pelo desmerecimento. Por trazer, em sua constituição étnico-racial, a origem africana, os povos ribeirinhos da região de Xique-Xique, cuja colonização se deu com a presença de africanos escravizados, não deixam de apresentar uma memória corporal de um tempo de humilhação e sofrimento. Todavia, o corpo afrodescendente apresenta uma trajetória que parte da dor e da subalternização para adotar práticas de resistência, de superação. A memória desses corpos, então, reinventa tradições para vencer o preconceito, o desmerecimento ainda presente na contemporaneidade como consequência de uma ideologia do branqueamento, implantada por um processo de colonização mental pelo branco europeu.

A ginga da capoeira, a pisada, o giro das rodas de samba e o ritmo das suas palmas mantiveram-se na memória corporal como estratégia de sobrevivência de uma cultura que vem sofrendo com as estratégias de apagamento, através da manipulação da própria memória. Conforme destaca Candau (2011, p. 167),

No Brasil, a manipulação da memória pelos brancos consiste em manter a memória da escravidão, pois esta é concebida como um meio de inferiorizar os negros, construindo uma identidade americana ou euro-americana com lembrança 'afro'.

Por meio de práticas culturais como o samba e outros gêneros da poética oral, os integrantes das rodas do samba ribeirinho - em sua maioria, afrodescendentes - navegam em águas turbulentas, contra essa corrente, buscando inverter tal realidade. O corpo deixa esquecido, em sua memória, as marcas de um passado submisso e de perdas, passando a aflorar a alegria das cantigas com suas danças, gingados e ritmos. O batuque do samba, a alegria, a determinação fazem que a cultura das margens se fortaleça gradativamente, dentro da pluralidade e da movência das memórias.

Dessa maneira, o corpo se move, dinamiza-se para fazer emergir uma memória, considerada por Candau (2011) como uma escolha, uma adaptação. Dorme, 
nesse momento, o corpo objeto, escravizado, oprimido, lúgubre. Desperta, então, o corpo viril, rebelde, resistente, esperançoso.

\section{Dança, performance e representação teatral na poética ribeirinha}

O corpo, através de sua performance, entendida aqui como o desempenho, a maneira de atuar, de realizar e de se comportar durante uma apresentação, por meio de toda uma poética e política, conforme Lopes (2012), acaba funcionando para o artista (nesse caso, as sambadeiras e sambadores) como um impulso catalisador, acompanhando o mapa de valores sociais, estéticos e políticos na tecedura simbólica presente nas várias regiões do Brasil, a exemplo da região de Xique-Xique.

Não se pode pensar em separar a poética da política, nem a política da festa, pois, como forma de manifestação da cultura popular, as rodas de samba e demais apresentações do grupo compõem-se de posicionamentos políticos. São elas (as rodas de samba e demais apresentações) os próprios atos políticos, devido ao fato de estarem carregadas de intenções, posicionamentos críticos que acabam agindo na própria conduta social do grupo, na consolidação e no fortalecimento das próprias manifestações.

O corpo, atuando nessas manifestações, através das práticas performáticas como danças, gestos e vozes, também se vale do posicionamento político, numa espécie de política do corpo, pois, nesse âmbito de representações, o corpo, conforme versa Merleau-Ponty (1999), não é neutro, mas se encontra carregado de intenções, valores e significações que ele deixa transparecer ou exprimir. O corpo passa a agir como uma extensão do mundo, da memória e das tradições, já que, ainda consoante Merleau-Ponty (1999), o corpo é no mundo, está integrado a ele.

Assim sendo, o corpo insere-se no espaço da poesia oral por meio da performance, considerada por Zumthor (2005, p. 87), como "uma realização poética plena: as palavras nela são tomadas num conjunto gestual, sonoro, circunstancial tão coerente (em princípio) que, mesmo se se distinguem mal palavras e frases, esse conjunto como tal faz sentido". 
A poesia e a dança se dão as mãos nas rodas de samba do grupo "É na pisada ê”, para, através de toda uma conjuntura performática, constituir a trama poética das margens do Velho Chico. Ao cantar e dançar, os participantes das rodas de samba reescrevem a sua poesia, deixando-a mais marcante, tornando-a mais completa no sentido de perpetuar as suas tradições.

O canto e a dança se apossam do corpo, elemento indispensável na configuração performática, para dar vida e sentido à própria poesia oral, já que esta não poderia existir sem a presença da voz, do gesto, do ritmo, da entonação e de demais elementos que compõem tal modalidade poética. Contudo, esse corpo, dentro das manifestações poéticas, passa a ser visto não apenas como um instrumento indispensável para a configuração dessas manifestações, mas vai além disso, pois o corpo é, nesses momentos, o próprio texto, carregado de falas, de ideologias e intenções. Consoante Zumthor (2005), o corpo leva ao nosso conhecimento (ao representá-lo, no sentido cênico da palavra) o discurso no qual se sustenta a poesia.

A dança assume um lugar preponderante dentro da poética do samba de roda em estudo, visto que, conforme Zumthor (2010), a dança, quando vem acompanhada de canto, este chega a prolongar, sublinhar e esclarecer um determinado movimento. Na dança da piranha, cuja cantiga já foi apresentada anteriormente, o canto, sincronizado com os movimentos de mexer com o corpo, colocando a mão na cabeça e na cintura, e dando a umbigada na outra sambadeira, serve para prolongar, marcar e esclarecer os respectivos movimentos, gestos e coreografias.

A dança é um detalhamento prazeroso das cantigas, é como se elas fossem escritas, desenhadas pelo corpo, pelos gestos, pelas coreografias. A dança traz para a poesia oral toda uma complementação do seu texto poético, enriquece-o e o faz transcender da marginalidade relegada por águas elitistas e eurocêntricas, para se tornar expressiva e, cada vez mais, parte fundamental na composição da grande rede poética que compõe o cenário nacional.

Os versos cantados durante a dança da Sinhá Furrudunga não seriam os mesmos, não teriam a mesma beleza nem expressividade se fossem cantados, descontextualizados, fora da representação performática criada com a utilização das malhas de tecidos coloridos, com seus movimentos circulares e em espiral, às vezes por cima, às vezes por baixo, como são reforçados os gestos, pelos próprios versos da cantiga: 
É por cima ou por baixo, Sinhá Furrudunga

É por cima ou por baixo, Sinhá Furrudunga

Toda a roda de samba e demais apresentações se constituem em grandes momentos de alegria e divertimento, e, sobretudo, de cantar toda uma história, com seus costumes, suas ideologias, crenças, dores, enfim, de alimentar a manutenção das tradições. A dança, aliada ao canto, dá mais vez e voz à poética oral desse samba de roda das margens do Velho Chico, pois

\begin{abstract}
A dança, prazer puro, pulsão corporal sem outro pretexto que ela própria é, também por isso mesmo, consciência. Tanto a dança de um só, quanto a de casal ou a coletiva, todos os tipos de dança aumentam a percepção calorosa de uma unanimidade possível. Um contrato se renova, assinado pelo corpo, selado pela efígie de sua forma, liberada por um instante. A dança expande, em sua plenitude, qualidades comuns a todos os gestos humanos. Ela manifesta o que se oculta alhures, revela o reprimido; faz desabrochar o erotismo latente. (ZUMTHOR, 2010, p. 226)
\end{abstract}

Como se pode notar, a poética do corpo se consolida em sintonia com a dança, com os rituais, com toda a estrutura que se monta numa espécie de apresentação teatral nas praças, nos salões comunitários, na porta de casa ou em eventos culturais da cidade. Os passos, os gingados, as pisadas mantêm-se da forma como manda a tradição, embora venham ocorrendo modificações pela incorporação de novas formas de dançar, inclusive dos "jeitinhos do corpo com a mão na cabeça e na cintura" e das "pisadinhas" das sambadeiras, especialmente das mais jovens.

Nessa poética corporal, a performance atua como algo vivo, que se firma na incompletude e no improviso. É algo que, como as águas do rio, está sempre em movimento, tornando-se diferenciada e única a cada apresentação das sambadeiras e sambadores, os quais buscam transmitir todo um conhecimento presente na memória coletiva de uma comunidade poética.

Segundo Zumthor (2007), a performance e o conhecimento daquilo que se propõe transmitir encontram-se ligados naquilo que a natureza da própria performance afeta o que se conhece, pois, de qualquer maneira, o conhecimento 
acaba sendo modificado pela performance com seus elementos marcantes. "Ela não é simplesmente um meio de comunicação: comunicando, ela o marca”. (ZUMTHOR, 2007, p. 32)

Através da performance, o corpo fala, grita, silencia-se, traz, em si, as marcas, os valores, o retrato de uma ancestralidade que se pinta a cada dia, em meio a uma nova realidade, construindo-se assim uma nova tradição, uma tradição “(re)inventada”. Esse corpo que canta e dança adequa-se à sua realidade, à cultura da qual faz parte e, em seu discurso, traz, de modo subjetivo, a sua história, ideologias e valores. Zumthor (2005, p. 145), a respeito da voz e do corpo na poesia, também destaca que:

O efeito poético é tanto mais forte quanto melhor soa a voz: nos interstícios da linguagem imiscui-se, pela operação vocal, o desejo de se desvencilhar dos laços da língua natural, de se evadir diante de uma plenitude que não será mais do que pura presença. Os impulsos deste desejo são amplificados pelo próprio funcionamento da voz na escuta coletiva: não isolada, não separada da ação, a voz poética é funcionalizada como um jogo, na mesma ordem dos jogos do corpo, dos quais ela participa realmente.

Nessas rodas de samba, há um envolvimento coletivo, uma sintonia instantânea de todos entre si e com a música, o ritmo e a letra. Nesse momento de sintonia, tudo se harmoniza e flui de forma cadenciada, cujas pisadas firmes, os giros, as umbigadas compõem todo o quadro performático. Harmonicamente, esses corpos passam a comungar de um discurso coletivo, mas que só vem a se consolidar nas práticas performáticas individuais de cada um desses integrantes, fortalecendo, com suas vozes cantadas, o efeito de toda a sua esplendorosa poética, pois "a performance comporta um efeito profundo na economia afetiva e, pode ocasionar grandes perturbações emotivas no ouvinte, envolvido nesta luta travada pela voz com o universo do entorno". (ZUMTHOR, 2005, p. 93) E nesses giros, pisadas e cantos, sambadeiras e sambadores, inquietam, emocionam e conduzem seus interlocutores pelo universo ideológico de sua poesia.

Em geral, as cantigas seguem um curso sequenciado, gerando, a cada nova letra, uma reação de alegria e animação dos participantes. Todos demonstram 
felicidade e envolvimento com a dança. Uma felicidade coletiva se espalha pela roda. Mesmo suados e adentrando a madrugada, o cansaço parece não chegar.

Segundo Zumthor (2007), essas cantigas do samba de roda, atos de comunicação poética, requerem a presença corporal de intérprete (o sambador ao centro da roda) e de ouvintes (demais participantes). Ainda conforme o referido autor, nesse momento de comunicação, vozes, ouvidos e corpos se unem em meio a um contexto situacional do qual todos os elementos visuais, auditivos e táteis se lançam à percepção sensorial, em uma espécie de representação teatral.

Nesse sentido, faz-se necessário considerar que, conforme versa Nogueira (2012, p. 54), “a palavra poética convoca a totalidade dos indivíduos presentes durante a performance, resultando em ação colectiva. O saber transmite-se de forma viva e, por intermédio do dizer poético, as estruturas da sociedade saem reforçadas". Através desse "dizer poético", durante os atos performáticos, as ideologias, os costumes, os valores são revelados, enfim o retrato social do grupo é pintado.

A performance do samba de roda do grupo tem um caráter inclusivo, pois mesmo não sendo integrante do grupo, qualquer visitante ou pessoa que esteja nas rodas e apresentações pode adentrar ao centro e sambar voluntariamente ou através de convite de umas das sambadeiras ou sambadores. Dessa forma, no samba de roda, conforme registra o Dossiê do samba de roda do Recôncavo baiano (2006, p. 24), "todos os presentes, mesmo os que ali estejam pela primeira vez, são, em princípio, instados a participar, cantando as respostas orais, batendo palmas no ritmo e até mesmo dançando no meio da roda caso a ocasião se apresente”.

A participação ocorre de forma espontânea ou pelo convite através da umbigada, marca comum na história do samba, presente nas rodas do grupo. E assim, nesse momento, ao ritmo das palmas, do batuque e dos sons dos objetos de percussão e demais instrumentos, todos compõem a roda e demonstram ter o gingado na memória do corpo, uma vez que não se ensina a sambar. Samba-se por si mesmo, pela memória corporal, repassada através das gerações.

Quando se utiliza a expressão "memória do corpo", não se tem a intenção de se referir a uma memória genética, como se o modo de sambar fosse repassado através de células ou genes, mas a uma memória que habita nos espaços da cultura, fazendo que, mesmo sem se dar conta, cada integrante de uma referida comunidade internalize, memorize os passos, as pisadas, a maneira de sambar. 
Isso ocorre porque, em consonância com Porter (1992), as relações mente/ corpo não são inatas, mas dependem da cultura. E o corpo não pode ser tratado simplesmente como biológico, deve, sim, ser considerado, conforme o caso deste estudo, como mediado por sistemas de sinais culturais. É uma memória cultural que habita o corpo por intermédio das práticas culturais, sendo transmitida e perpetuada através dos próprios integrantes de geração a geração.

Fala-se, portanto, de uma memória corporal como uma ligação à cultura, como uma memória que se consolida pela vivência no grupo cultural. Sendo assim, pode-se afirmar que a memória corporal é resultante das experiências e do contato com a cultura e suas práticas, porque:

[...] corpo e memória constituem-se historicamente, sendo indissociáveis entre povos de matrizes orais. Saberes, costumes, tradições, produzidos e transmitidos em presença de corpos, materializam-se em gêneros não-verbais de memórias, emitindo vozes do corpo prolongadas em artefatos de suas culturas. (ANTONACCI, 2009, p. 104)

Em meio a todo esse conjunto performático, os participantes do grupo "É na pisada ê" acabam, portanto, praticando, nessas rodas de samba, uma espécie de batuque, aqui representado, sob a ótica de Siqueira (2012, p. 44-45), como:

[...] de significado onomatopaico-rítmico, de bater, batuque, batucada - ação de 'bater', de percutir em tambores, caixas, fragmentos de madeira, tamborins e até chapéus de palheta, como também de executar passos 'sapateados' na dança. Ao invés do batuque, cujo significado se vê reduzido, o samba amplia-se e generaliza-se.

O batuque, então, assume uma significação abrangente de toda espécie de dança, geralmente em círculo, marcada por ritmos e passos africanos que chegaram ao Brasil, por meio dos negros escravizados e que assume, conforme afirma Siqueira (2012), outros nomes, inclusive o de samba. Em geral, a umbigada acompanha todas as apresentações.

Não se pode esquecer ainda das vestimentas, dos adornos e adereços como elementos que contribuem para a composição dessa poética corporal, constituindo-se, juntamente com o cenário e os instrumentos musicais, numa espécie de complementação à performance da dança. São também parte integrante de 
toda a performance poética, pois, segundo Zumthor (2010), o gesto, a roupa, o cenário e a voz se projetam no lugar da performance, embora os elementos que compõem cada um deles, como os movimentos corporais, as formas, as cores, as tonalidades e as palavras da linguagem passam a compor, juntos, um código simbólico do espaço.

Os trajes utilizados pelas sambadeiras são compostos de saias coloridas e rodadas, colares e outros adornos, além de lenços amarrados no pescoço ou na cintura, flores no cabelo, pulseiras e anéis. A maquiagem é também indispensável para as mulheres, especialmente o batom. Igualmente, o perfume. Cores e aromas irmanam-se na composição da cena poética.

Em linhas gerais, os homens sambam na roda poucas vezes, embora acompanhem o ritual cantando, tocando os instrumentos e batendo palmas. Vestemse de maneira comum, alguns de chapéus, uma marca da tradição local. Assim sendo, como versa Zumthor (2010, p. 225):

Todas as culturas humanas parecem colaborar com algum vasto teatro do corpo, de manifestações infinitamente variadas, com técnicas tão diversificadas quanto nossos gestos cotidianos, em cuja cena a poesia oral aparece, frequentemente, como uma das ações que ali representam.

O corpo ocupa, portanto, um lugar de destaque nessa teatralidade que se estabelece durante as apresentações do samba de roda. Às vezes, nessas manifestações, mesmo que todo o corpo se mova e participe das rodas, há sempre um de seus gestos que é mais carregado de significação que outros. É o caso da umbigada ao final da apresentação de cada sambadeira na roda.

A teatralidade passa a ser entendida nessa concepção como um termo polissêmico, que inclui a performatividade e depende da leitura do espectador para se constituir, pois, segundo Fernandes (2011), a teatralidade é proposta como meio privilegiado de fusão do drama, da música, da poesia e do gesto. Nesse ínterim, a performatividade passa a compor a representação teatral como elemento produtivo, indispensável, vez que os traços performativos permeiam a linguagem teatral e está sempre em processo de reelaboração. 
[...] a performance nunca é um objeto ou uma obra acabada, mas sempre um processo, por estar ligada ao domínio do fazer e ao princípio da ação [...] a arte da performance visa exatamente a desestabilizar o cotidiano por meio da transgressão e da ruptura, promovendo ações artísticas marcadas pela diferença. (FERNANDES, 2011, p. 16)

Isso se faz notório nas rodas do grupo de samba "É na pisada ê", quando as mulheres entram na roda com uma performance específica, enquanto todos cantam repetidamente e cada vez mais acelerado:

Essa mulher tá doida, tá doida tá

Essa mulher tá doida, tá doida tá

A mulher lava a roupa doida

A mulher pega a água doida

A mulher pega a lenha doida

A mulher lava os trem doida

Essa mulher tá doida, tá doida tá

Essa mulher tá doida, tá doida tá

Nesse momento, elas começam a sambar em um ritmo mais frenético, rodando, fazendo gestos com as mãos junto à cabeça como se estivessem loucas, desorientadas.

Toda a roda de samba acaba se configurando numa espécie de representação teatral, na qual, em cada estrofe cantada, há sempre uma performance apropriada com a adoção de gestos e movimentos relacionados à letra. Como outro exemplo, pode-se apresentar a cantiga:

Ô pega a cadeira

E assenta mulher

A mulher que não assenta

Que diabo quer em pé?

Nesse caso, há elementos cenográficos incorporados ao ambiente como a cadeira. Enquanto as pessoas da roda cantam os versos, a mulher pega a cadeira e "assenta”, mas não permanece sentada, como se hesitasse em sentar e acatar as ordens do grupo. Em todo o percurso da representação, a mulher ora samba 
em pé, ora se senta na cadeira, ora circula ao seu redor. Os demais integrantes da roda agem como se estivessem mandando a mulher sentar. E esta, ao centro, cumpre todo um ritual performático, sempre acompanhada de muita alegria. Em outro momento, os integrantes cantam:

Ô barre a casa, mulher

Eu mandei

Ô barre a casa, mulher

Eu não sei não

E o jogo performático se estabelece mais uma vez, quando todos começam a representar como se estivessem com uma vassoura varrendo, e uma sambadeira permanece no meio da roda, fazendo gestos negando, para dizer que não sabe varrer. O texto das cantigas parecem ser feitos para dançar e representar. As cantigas, como muitas das aqui apresentadas, aparentam ter seus textos determinados por sua funções. Isso se comprova nas cantigas como essa em que a mulher simula, com gestos, "barrer” a casa, também na que é orientada a pegar a cadeira e "assentar".

Além dessas, há várias outras, cujos gestos, performances e danças parecem ser verbalizados pelo seu texto. É o caso ainda da cantiga da piranha, já apresentada, cujo texto determina que a sambadeira ponha a mão na cabeça e na cintura, faça um "jeitinho" no corpo e dê uma umbigada na outra.

Como ocorre nas composições do samba de roda, relações como estas - entre o texto e o gesto, a dança, a performance - são discutidas por Zumthor (2010, p. 228), quando afirma que:

O texto das canções para dançar, determinado por sua função, se parece com o gesto que ele verbaliza. Breve, curto, reduzido ao apelo, à exclamação alusiva, à sentença, ou mais amplo, com largos contornos estróficos, prestando-se às modulações emotivas e às evocações míticas. A necessária recorrência regular de unidades rítmicas - gestuais, vocais, instrumentais e, por consequência, textuais - torna em contrapartida quase impossível a composição de canções de dança explicitamente narrativas. 
Essa forte relação entre corpo, performance e teatralidade irrompe nas cantigas que representam a sua lida, como quando tecem as redes de pesca:

Ô linha, linhava ô

Eu também sei linhar, ô linhava

Ô linha, linhava ô

Eu também sei linhar, ô linhava

Enquanto cantam - "Ô linha, linhava ô" -, representam o gesto dos carretéis de linha, como se estivessem tecendo as redes, seus instrumentos de pesca. Cantam, dançam, ao passo que representam a sua labuta cotidiana na tecedura das redes de pesca, feitas a partir de uma fibra extraída de algumas espécies de cipós encontrados na região ou mesmo de um tipo de fios de nylon.

Nesse universo representativo, de associação com elementos cotidianos, cenários e personagens ou com a própria história, a Dança do Guaxinim destacase como momento em que os participantes se entrelaçam na roda, inclinandose ora para um lado, ora para o outro, dando umbigadas e cantando de forma ritmada:

O guaxinim quando briga é assim

Cai para um canto, cai para o outro

O guaxinim quando briga é assim

Cai para um canto, cai para o outro

Há, nesse jogo corporal, toda uma sintonia de passos enquanto representam o samba do guaxinim, imitando a briga entre guaxinins, uma espécie de mamífero da fauna regional. Por meio de exemplos como esses, percebe-se como a performatividade e a teatralidade integram a cultura ribeirinha, contribuindo para representar os seus costumes, valores, religiosidade, através de manifestações como a poética do samba de roda.

A referência feita às expressões "teatral” e "teatralidade" não se apega a uma visão de teatro como a arte do fingimento nem da representação de obras dramáticas. A noção de teatralidade ou representação teatral trazida no decorrer deste estudo deve ser compreendida como uma espécie de organização, encenação e produção espetacular, conforme versa Vasconcellos (2009) em seu Dicionário de 
teatro. Considera-se essa representação teatral como uma apresentação de cenas e fatos cotidianos, como uma simulação da realidade, um ato ficcional que traz a representação de acontecimentos, de danças e dos próprios hábitos e afazeres, e nunca como um fingimento de algo criado.

Desse modo, o que se destaca não é o teatro como gênero dramático, forma de arte, mas os elementos que fazem parte do espetáculo, da representação, como a musicalidade, a dança, a performance, a coreografia, as vestimentas, os adereços e até a cenografia e o público. É uma espécie de ficção mais relacionada aos rituais, danças, cultos e outras práticas lúdicas, consideradas como formas que trazem, em si, os germes teatrais.

Além dos passos tradicionais, das pisadas ao ritmo das palmas e do som dos instrumentos tocados, em maioria, pelos homens do grupo, as mulheres arriscam coreografias que vão de requebros e de rodadas com a mão na cintura até a finalização de sua participação na roda com uma umbigada em outra sambadeira, convidando-a para adentrar ao centro e dar continuidade à "brincadeira", como muitos chamam o samba.

A umbigada, como se percebe, faz-se presente em grande parte das danças performatizadas pelo grupo de samba "É na pisada ê", reforçando, assim, a presença da afrodescendência como elemento formador. Como já foi mostrado, a umbigada chegou ao Brasil através dos negros escravizados e suas danças como o batuque. Segundo Cascudo (2008), ela faz parte das rodas de samba, que se originou da palavra semba, a qual significa bater no umbigo do outro.

\section{Riso e ludicidade na performance das sambadeiras e sambadores}

Dentro do viés performático das sambadeiras e sambadores das margens do Velho Chico, não se pode deixar de fazer emergir a veia humorística, a alegria e a ludicidade. A roda de samba traz, em si, a graça, o riso e a descontração, quando os participantes se utilizam das várias formas performáticas, com seus gestos e danças, representando os temas trazidos nas letras de cantigas. A seguir, novamente, traz-se uma dessas cantigas, a fim de tomá-la como exemplo mais uma vez: 
Essa mulher tá doida, tá doida tá

Essa mulher tá doida, tá doida tá

A mulher lava a roupa, doida

A mulher pega a água, doida

A mulher pega a lenha, doida

A mulher lava os trem, doida

A mulher barre a casa, doida...

Essa mulher tá doida, tá doida tá

Essa mulher tá doida, tá doida tá

Na representação dessa cantiga, a performance incorporada é de uma mulher em estado de loucura, completamente doida e descontrolada. Todas as sambadeiras, nesse momento, sambam de modo engraçado, desconexo, como se estivessem realmente malucas, desorientadas, atrapalhadas. O riso e a alegria dominam a roda, e o humor invade o universo dessa manifestação poética e festiva das margens do Velho Chico. Cada participante, então, procura sambar da forma mais engraçada que pode, com o intuito de provocar o riso, de chamar a atenção para si.

Sendo assim, em suas apresentações, o samba de roda ribeirinho mantém um diálogo constante com o humor. O lúdico permeia todo o jogo dos gestos, das danças, das pisadas, dos próprios giros e umbigadas, conforme se pode observar, ainda, quando entoam e representam suas cantigas, como a da piranha, apresentada aqui mais uma vez:

Dançou, dançou, piranha

Tornou dançar, piranha

Com a mão na cabeça, piranha

Com a mão na cintura, piranha

Dá um jeitinho no corpo, piranha

E uma umbigada na outra, piranha

Nessa cantiga, as sambadeiras agem como piranhas alvoroçadas, sambando também euforicamente, dando giros, umbigadas e inclinando o corpo para frente e para trás, com pisadas firmes e ritmadas, querendo representar a agitação e a valentia dessa espécie de peixe comum no Rio São Francisco. Nesse instante, é impossível resistir a boas risadas. 
A cantiga do guaxinim é considerada um outro momento de riso, alegria e descontração de toda a roda de samba, pois, enquanto cantam, tanto a solista ao centro da roda quanto os demais integrantes, sambam imitando um guaxinim, girando e se inclinando para um lado e para o outro, com movimentos rápidos, ariscos. A euforia e a agitação contribuem para que todos caiam em gargalhadas, procurando sambar de forma mais cômica possível, a fim de chamar a atenção e fazer o outro rir, conforme a cantiga:

O guaxinim quando briga é assim

Cai para um canto, cai para o outro

O guaxinim quando briga é assim

Cai para um canto, cai para o outro

Todos os participantes da roda de samba passam a simular, entre eles, uma briga de guaxinins, como sugere a própria cantiga, caindo para um lado e para o outro. No momento em que um integrante se aproxima do outro, chegam a se encostar frente a frente, enquanto um inclina o corpo para a esquerda e o outro para a direita, repetindo várias vezes.

A comicidade de performances como essa acaba induzindo ao riso, à alegria. Em momentos como esses, consolidam-se o humor e a graça, pois cada sambadeira e sambador tem seu jeito próprio de dançar, de representar a letra, sendo cada uma de maneira mais cômica. É comum que todos os participantes da roda deem risadas e participem mais freneticamente do samba. Nessa hora, as palmas ficam mais fortes, em ritmo mais acelerado, as pisadas e gingados também são mais intensos, muitas vezes descontrolados.

E a alegria, o riso e a descontração tomam conta de todos, quando de maneira engraçada e delirante, sambam imitando desde animais como peixes e guaxinins, até situações descritas nas cantigas, como "assentar-se” na cadeira, "barrer" a casa, dentre outras atividades performáticas. Entre giros, rodopios, pisadas e umbigadas se divertem em meio a uma série de risos.

Como se percebe, todo o samba de roda ribeirinho se constitui numa espécie de representação ficcional, na qual as sambadeiras e sambadores se utilizam do corpo e de elementos performáticos para trazer as cenas do seu cotidiano. Essa espécie de teatralidade ou ficção passa a proporcionar uma forma de preservação da história, da cultura ribeirinha. De forma lúdica, divertida e, na maioria 
das vezes, humorística, as tradições se mantêm vivas através da prática da roda de samba. Assim, o veio emotivo passa a reger toda a roda, e todos os seus partícipes mergulham em alegria.

\section{Dança da Sinhá Furrudunga}

Ainda como exemplo de ludicidade e representação performática no samba de roda ribeirinho, destaca-se a dança da Sinhá Furrudunga, na qual as sambadeiras fazem uma coreografia segurando algumas malhas de tecido, configurando alguns passos e movimentos acompanhados dos respectivos tecidos. As malhas se entrecruzam na dança, assim como as identidades ribeirinhas se entrelaçam para manter vivas, em suas tradições, a poética oral e as suas festas, cantigas e danças.

A dança constitui-se numa espécie de coreografia desenvolvida por um grupo de sambadeiras e sambadores que se dispõem aos pares, sendo homens de um lado e mulheres do outro, embora possa também haver vários pares formados por duas mulheres, não sendo obrigatória a associação entre um homem e uma mulher. Como o grupo é formado majoritariamente por mulheres, há vários pares compostos por duas mulheres, o que não ocorre com os homens, pois estes se agrupam apenas com uma mulher.

Na dança, cada par segura uma espécie de manto colorido, isto é, uma fita larga de tecido de grande comprimento. Enquanto giram em sentido horário e anti-horário, os pares vão trocando de lugares, entrelaçando os mantos, passando-os ora por cima, ora por baixo, enquanto cantam um verso que se repete entre uma cantiga e outra:

É por cima ou por baixo, Sinhá Furrudunga

É por cima ou por baixo, Sinhá Furrudunga

O objetivo da coreografia é, ao final, formar uma espécie de estrela com o entrelaçamento dos mantos coloridos. Além da estrela, há diversas formas para a utilização dos tecidos, que são também agitados em forma circular, ondular, espiralada. 
É muito comum, no seu dia a dia, os pescadores, especialmente as mulheres, tecerem as redes de pesca. Sentadas no terreiro ${ }^{18}$ de casa, elas tecem enquanto cantam suas cantigas, intermediadas por versos como os da cantiga a seguir:

Ô linha, linhava ô

Eu também sei linhar, ô linhava

Ô linha, linhava ô

Eu também sei linhar, ô linhava

Na dança da Sinhá Furrudunga, também fazem algo semelhante enquanto dançam a coreografia, cantam suas cantigas, as quais retratam o cotidiano, a história e os costumes do grupo, mas com outro tipo de verso que se repete, o qual traz uma referência à dança da Sinhá Furrudunga, como se pode observar:

Eu sou negociante

Vendo ouro e diamante

Eu não lhe dou dinheiro

Porque não tenho trocado

Só lhe dou vinte mil réis

Na despesa do sobrado

É por cima ou por baixo, Sinhá Furrudunga

É por cima ou por baixo, Sinhá Furrudunga

Essa noite choveu ouro

Prata fina alumiou

Quero que você me diga

Onde meu sentido andou

Onde meu sentido andou pra vadiar

Na dança da Sinhá Furrudunga, os passos coreografados, associados às cantigas, juntamente com os acessórios coloridos e trajes utilizados, contribuem para tornar ainda mais rica a poética oral ribeirinha. No exemplo anterior, en-

18 O termo "terreiro" refere-se a um espaço de terra, varrido e bem cuidado, que fica em frente às casas. As tecedeiras tecem as suas redes, geralmente, sentadas nesse espaço, à sombra de alguma árvore. 
quanto se remetem aos tempos áureos do garimpo e à riqueza das pedras e metais preciosos como o diamante, o ouro e a prata, desenham formas geométricas, enchem de cor e movimento a poesia das margens do Velho Chico.

E assim seguem durante toda a dança, revivendo, através das cantigas e performances, cenas de um cotidiano ou retratos de uma memória que permanece viva nesses espaços poéticos. São várias quadras que cantam os mais diversos temas, sendo intercaladas, como já demonstrado, pelo verso “É por cima ou por baixo, Sinhá Furrudunga”.

A dança traz à baila toda uma tradição que reúne elementos da cultura portuguesa, como alguns passos elaborados, as danças de pares, os instrumentos e vestimentas que lembram os bailares oriundos da Península Ibérica, que aqui chegaram através da colonização, sem contar as próprias cantigas que apresentam temas semelhantes, em sua maioria, à da poesia popular portuguesa.

Nessa dança, como também nas outras atividades do grupo, não se podem desprezar os outros vieses culturais de influência ameríndia e africana, embora a dança da Sinhá Furrundunga se aproxime mais de algumas danças portuguesas e não traga, tão expressivamente, elementos como a umbigada, a "pisadinha" ou miudinho - ambos de influência africana -, nem certas práticas das culturas indígenas, como a maneira de representar a dança de algumas aves e outros animais, inclusive na vestimenta e caracterização, conforme se faz na dança do guaxinim. Na dança da Sinhá Furrudunga, a presença da influência cultural dos povos ameríndios e afrodescendentes também se faz notória, ocorrendo em alguns adereços, passos, instrumentos musicais, na letra da música e, especialmente, no título da dança.

Todas essas manifestações poéticas, como até mesmo a dança da Sinhá Furrudunga, são criadas a partir dessa confluência de culturas, tendo surgido muitas vezes em uma matriz, mas sendo enriquecida em terras nordestinas das margens do Velho Chico com marcas de outras culturas.

Quanto ao título da dança, Sinhá Furrudunga, sabe-se que a expressão "sinhá”, segundo Cascudo (2008), é uma corruptela de "senhora”, termo originariamente usado pelos africanos escravizados, para chamar as mulheres de seus senhores. Dessa forma, tornou-se comum encontrar, por todo o cancioneiro popular do Brasil, a expressão "sinhá" como referência em alguns versos, inclusive nomeando algumas cantigas e danças. A expressão passou a fazer parte do vocabulário nordestino e mesmo "desaparecidos os escravos, sinhá passou 
a ser apelido doméstico, comum no Nordeste”. (CASCUDO, 2008, p. 638) Logo, subtende-se que a dança da Sinhá Furrudunga seja uma forma de reverenciar, homenagear uma senhora de boa índole, de família abastada e de bom coração, a qual mantinha uma certa notoriedade na época, dentro da comunidade.

Quanto ao termo "Furrundunga”, há indícios de que seja uma variante de "furundunga", feminino de "furundungo", que significa "andarilho, de provável origem banta, termo usual em Santa Catarina”, conforme o Novo dicionário banto do Brasil, de Nei Lopes. (2003, p.105) Em alguns versos, o eu lírico interpela a "sinhá" andarilha: "Quero que você me diga/ Onde meu sentido andou/ Onde meu sentido andou pra vadiar".

Segundo relatos das sambadeiras do grupo em suas falas, essa dança foi criada há tempos por uma senhora, esposa de um fazendeiro da região, que ensinava os passos e ensaiava constantemente um grupo de pessoas para se apresentar nas festas promovidas pela Igreja Católica, quase sempre, após a celebração das missas. Ainda de acordo com os relatos das sambadeiras, a família da "sinhá" que realizava a dança era conhecida como "os furrudunga”. Tal expressão, nesse caso, pode ser considerada como um apelido relacionado às andanças da referida família - ou apenas da "sinhá" -, talvez vinda de lugar longínquo, a exemplo do sul do país, onde o termo é bastante usual, conforme Lopes (2003).

Essa dança vem sendo apresentada até hoje, nas festas de padroeiros, como a de São Pedro, que dá nome ao bairro. O grupo também costuma apresentar essa dança em outras programações culturais da cidade, festas de escolas, eventos promovidos pela UNEB, através do campus de Xique-Xique, dentre outras.

É muito bonito de se apreciar, de se perceber as figuras e os formatos criados pela coreografia com os tecidos coloridos. Mais bonito ainda é perceber, nessas manifestações poéticas, a tecedura das identidades, das culturas das margens do Velho Chico, que traz toda uma riqueza de temas, ritmos, gingados e performances, construídos sob a forma de uma rede pluricultural, tecida a partir de diversos fios. 